\title{
Novice Teachers' Challenges and Problems in Bilingual Schools Context in Bali
}

\author{
Eka Anastasia Wijaya ${ }^{1 *}$, Made Hery Santosa ${ }^{2}$ \\ ${ }^{1,2}$ English Language Education, Post-Graduate Program, Universitas Pendidikan Ganesha, Indonesia \\ *Corresponding author. E-Mail: eka.anastasia@undiksha.ac.id
}

\begin{abstract}
The present study aimed to investigate the problems and challenges encountered by novice English teachers in two major bilingual schools located in different regions in Bali. Framed within a qualitative design, the study employed survey and interview as the methods with a questionnaire and an interview guide as the instruments to collect the data. The obtained data were analysed using Interactive Model Analysis supported by data triangulation. The result showed that the problems and challenges faced by the novice English teachers were derived from various internal and external factors, comprising 1) teachers' preparation as the internal problem, 2) relationship with other teachers and parents as the external problem, 3) assessment and curriculum as the internal challenges, and 4) students' attitudes as the external challenge. There is an emerging phenomenon where many novice teachers in the bilingual schools in Bali lacks of supports in terms of bilingual teacher instructional concepts, training, and professional developments. It implies that novice bilingual teachers need to develop their pedagogical practices with teacher training and bilingual education course in their educational level sustainably within the framework of continuing professional development.
\end{abstract}

Keywords: novice teachers, bilingual education, challenges, problems

\section{INTRODUCTION}

\subsection{Research Background}

The emergence of bilingual schools in today's era become popular in line with the existence of English as international communication language. It is supported by [6] and [24], in which bilingual education is a popular topic among educators in today's schools. Besides, the emergence of bilingual schools also become very popular in Indonesia [29]. However, it seems that not all educators know how to handle students in bilingual schools although the teachers' role is crucial on the practical implementation of bilingual education [6].

In line with that, one of the interesting phenomena to be investigated is how novice English teachers face the environment in bilingual education including bilingual schools and bilingual students since they have not any course that discuss about bilingual education in their previous educational process. A literature study from [24] has the same focus with this phenomenon in which the teachers in bilingual school need to be supported through a course with specific goals about bilingual education in their previous educational level. In line with that, a study from [6] found that it is needed to focus on the teachers' role in bilingual schools, especially how the bilingual teachers are educated previously. In this case, novice teachers are teachers who have teaching experience less than three years or up to two years and have just implemented their teaching skills with basic classroom routines [3][5][1].
The teaching and learning experiences in bilingual school and regular school will be different. It is supported by [11], in which bilingual class is a new learning experience. Moreover, [1] stated that novice teachers encountered many challenges in their initial years of teaching. The challenges could be seen in the fact that many novice English teachers are lack of experience in bilingual class. In this case, having a bilingual class will help the teachers to learn specialty knowledge in bilingual class [11]. [1] added that a proper conducive teaching and learning environment as well as administrative and academic support would affect the teacher's future teaching process.

In line with that, [6] and [24] stated that the educators in bilingual education have to be provided with support in creating opportunities to build a proper educational environment for the students. This kind of support could be seen in the educational process in form of course about bilingual education for the future teachers. It is supported by [6], in which it is important to focus on how the teachers are educated previously. The other support could be seen in teacher training for the future teachers [6]. In this case, the training could help the future teachers to prepare themselves in facing bilingual education to avoid misconception. The same opinion comes from [15], in which the lack of teachertraining including the teachers' unpreparedness becomes one of the problems encountered in the multilingual education.

As above, it could be said that not all novice teachers know how to teach in bilingual schools. Besides, the lack of bilingual course in the previous educational level from the teachers and the lack of teacher training are also becoming the 
issues in the implementation of bilingual education. However, the fact in the local context in Bali showed that there are many novice English teachers graduated from English Language Education major become teachers in bilingual schools. Alongside with that condition, it might cause several challenges and problems faced by the novice English teachers. In this case, this study took place in North Bali Bilingual School (NBBS) and Bukit Sunrise School as two major bilingual schools in Bali. Thus, this present study examined the novice teachers' challenges and problems in facing the environment in NBBS and Bukit Sunrise School as bilingual schools.

\subsection{Research Problem}

Several previous studies indicated that many novice English teachers have to face the environment in bilingual education with limited background knowledge about bilingual education itself. Further, in the local context especially in Bali, there are many novice English teachers graduated from English Language Education major from one of public university in North Bali who become bilingual teachers although they have not any course that discuss about bilingual education in their previous educational process at the university level. Besides, there is no teacher training for novice English teachers to prepare themselves in facing bilingual education and its parts. Alongside with that condition, there might be several challenges and problems faced by the novice English teachers during the teaching and learning process in bilingual schools context. Therefore, this study examined the challenges and problems faced by the novice English teachers in two major bilingual schools in Bali.

\subsection{Review of Literature}

There are several previous studies related to the problems and challenges encountered by the teachers in bilingual schools conducted by [9], [2], [8], [25], [29], [24], and [6]. From those studies, it is concluded that there are several problems and challenges faced by the teachers in bilingual schools. In this case, the problems and challenges could be classified into internal and external. However, none of the previous studies presents a vivid description of the problems and challenges encountered by novice English teachers in bilingual schools as well as its solution, whether the problems and challenges encountered by novice English teachers will be the same with experienced teachers or not. Because of that, those empirical studies lead the researcher to examined the problems and challenges faced by novice English teachers in bilingual schools as well as its solution.

\subsection{Research Questions}

This research aimed to answer two research questions:

1) What are the novice English teachers' challenges and problems in NBBS and Bukit Sunrise School as bilingual schools in Bali?
2) How the novice English teachers deal with the challenges and problems in NBBS and Bukit Sunrise School as bilingual schools in Bali?

\section{METHOD}

\subsection{Research Design}

This study was in form of qualitative research. According to [13], qualitative research describes social phenomena that happen naturally. In this case, the social phenomenon was the problems and challenges faced by novice English teachers in bilingual schools context especially at North Bali Bilingual School (NBBS) and Bukit Sunrise School as well as the solution given by the teachers to face the problems and challenges. Thus, this research examined the problems and challenges faced by novice English teachers in bilingual schools context in Bali and its solution.

\subsection{Setting and Participant}

From the preliminary interview, NBBS and Bukit Sunrise School have been seen as suitable examples of the teaching and learning process implemented by novice English teachers from English Language Education (ELE) major graduated in one of public university in North Bali who teach at bilingual schools. Moreover, NBBS and Bukit Sunrise School have been seen as suitable examples because many novice English teachers in there were from the major mentioned before. Therefore, this research was conducted at NBBS that is located at Jalan Ki Barak Panji, Desa Panji, Sukasada Subdistrict, Buleleng Regency and Bukit Sunrise School that is located at Perumahan Kencana Resort I/88, Ungasan, Jimbaran.

The subjects of this present study were four novice English teachers graduated from ELE in one of public university in North Bali who teach at NBBS and Bukit Sunrise School. The followings were the considerations in choosing the subjects:

1) The teachers are novice or new teachers graduated from ELE major in one of the public university in North Bali mentioned before who teach at NBBS and Bukit Sunrise School.

2) The category to be considered as novice teachers in this study will be those who have teaching experience less than three years or up to two years.

3) The teachers are willing to be the subject of this research.

\subsection{Data Collection Method and Analysis}

In collecting the data, the researcher used two methods namely survey method and interview method with a questionnaire and an interview guide as the instruments. The explanation could be seen as follows.

1) Methods of Data Collection 
a) Survey Method

The researcher used survey method to find the data about novice English teachers' problems and challenges in bilingual schools context. In this case, it employed a questionnaire as the instrument.

b) Interview Method

The researcher used interview method to enrich the data about novice English teachers' problems and challenges in bilingual schools context as well as the solution given and done by the novice teachers itself. The interview was in form of open-ended interview to let the subjects explain their answers in detail.

2) Research Instruments

\section{a) Questionnaire}

The researcher used a questionnaire to ask the problems and challenges faced by the novice
English teachers in the context of bilingual schools. The questionnaire was developed based on the blueprint adapted from [22] and [27], as seen in Table 1.

b) Interview Guide

The researcher used an open-ended interview guide to collect the data about the problems and challenges faced by the novice teachers during the learning process at NBBS and Bukit Sunrise School as well as its solution to cover the problems and challenges. The interview was conducted after the data from the questionnaire were being analysed. The interview guide was developed based on the blueprint adapted from [22] and [27], as seen in Table 1.

Table 1. Blueprint for Questionnaire and Interview Guide

\begin{tabular}{|c|c|c|c|c|c|}
\hline \multirow{2}{*}{ Theory } & \multirow{2}{*}{\multicolumn{2}{|c|}{ Aspect }} & \multirow{2}{*}{ Indicator } & Questionnaire & Interview Guide \\
\hline & & & & \multicolumn{2}{|c|}{ Item Number } \\
\hline \multirow{4}{*}{$\begin{array}{l}\text { Öztürk and } \\
\text { Yildirim } \\
\text { (2013) }\end{array}$} & \multirow[t]{4}{*}{ Challenges } & Assessment & $\begin{array}{l}\text { Teachers have to design appropriate } \\
\text { assessment for the students }\end{array}$ & 1 & 1 \\
\hline & & Curriculum & $\begin{array}{l}\text { Teachers have to understand the } \\
\text { curriculum used in the school }\end{array}$ & 2 & 2 \\
\hline & & $\begin{array}{l}\text { Other Teachers' } \\
\text { Attitudes }\end{array}$ & $\begin{array}{l}\text { Other teachers' attitudes affect the novice } \\
\text { teachers' progress }\end{array}$ & 3 & - \\
\hline & & Students' Attitudes & $\begin{array}{l}\text { Teachers have to deal with the students' } \\
\text { different attitudes }\end{array}$ & 4 & 3 \\
\hline \multirow[t]{4}{*}{$\begin{array}{l}\text { Veenman } \\
(\mathbf{1 9 8 4 )}\end{array}$} & \multirow[t]{4}{*}{ Problems } & $\begin{array}{l}\text { Teaching } \\
\text { Preparation }\end{array}$ & $\begin{array}{l}\text { Teachers have to prepare well before the } \\
\text { teaching practice }\end{array}$ & 5 & 4 \\
\hline & & $\begin{array}{l}\text { Classroom } \\
\text { Management }\end{array}$ & $\begin{array}{l}\text { Teachers have to manage well the } \\
\text { classroom }\end{array}$ & 6 & - \\
\hline & & Students' Attitudes & $\begin{array}{l}\text { Teachers have to deal with the diversity of } \\
\text { students' attitudes }\end{array}$ & 7 & - \\
\hline & & $\begin{array}{l}\text { Relationship with } \\
\text { Other Parties }\end{array}$ & $\begin{array}{l}\text { Teachers have to build a good relationship } \\
\text { with other parties such as other teachers } \\
\text { and parents }\end{array}$ & 8 & 5 \\
\hline
\end{tabular}

\section{3) Data Analysis}

In this research, the data about the problems and challenges faced by novice English teachers at NBBS and Bukit Sunrise School and its solution were analysed using Interactive Model Analysis. According to [17], data analysis consists of three flows which are data reduction, data display, and verification or conclusion drawing.

1. Data reduction

After collecting the data about the novice English teachers' challenges and problems from the questionnaire, the obtained data from the questionnaire were analyzed to develop the questions in the interview guide. Therefore, the data about the novice English teachers' solutions toward the challenges and problems were obtained through an interview. Then, those two kinds of data were simplified and transformed to be analyzed in the data display.

2. Data display
In the data display, those two kinds of data were displayed in form of tables and description.

3. Verification or conclusion drawing In the verification, the researcher elaborated the obtained data into two important points namely 1) novice English teachers' challenges in bilingual schools and its solution and 2) novice English teachers problems in bilingual schools and its solution.

\section{FINDINGS AND DISCUSSION}

\subsection{Novice English Teachers' Challenges in Bilingual School and the Solutions}

Based on the result of questionnaire and interview, it shows that the novice teachers' challenges in bilingual schools are classified into internal and external challenges. The internal challenges were assessment and curriculum. Meanwhile, the external challenge is students' attitudes. 
The first internal challenge that is assessment showed that the novice teachers considered the use of two curriculum in the school, namely Cambridge curriculum and Kurikulum 2013 , affect the assessment process. In this case, the use of two curriculum required the teachers to use two types of assessment following the curriculum. Related with that challenge, the teachers as well as the school principals follow several training and workshop to help the novice teachers in dealing with the challenge in term of assessment. [28] added that the intensity and duration of the program are the crucial factors related with designing a professional development program. Therefore, it is needed to consider the intensity and the duration of the training as well the workshop. For the international curriculum, Cambridge curriculum, the school principals give the novice teachers chance to follow Webinar of Cambridge assessment with certain course in line with the course being taught by the teachers each three months. In line with that, [15] stated that seminars or workshops are important for bilingual teachers because the bilingual teachers need to be guided on how to handle bilingual students. Further, [3] stated that the schools and the government should provide opportunities and supports for novice teachers to maximize their knowledge related with teaching and learning process as well as maximizing the novice teachers' development. Meanwhile, for the national curriculum, Kurikulum 2013, the headmaster and the senior teacher will join the training called as Asesmen Kompetensi Minimum $(A K M)$ and share the information to the novice teachers. This training help the teachers to deeper their knowledge and understanding of how to assess the students' competency for the real context. [9] supported that training for bilingual teachers is needed and marked as ongoing professional development.

The other challenge in term of assessment is how to suit the developed assessment from school with the students' diversity. Sometimes, the developed assessment cannot cover all of the students' diversity. It is because the school have their own guideline or principle in developing the assessment. To cover this challenge, the novice teacher is not always depend on the summative assessment but also consider the formative assessment. [12] and [19] has the same opinion, in which language teachers have to be able to choose or select the most appropriate assessment for the students.

The second internal challenge is curriculum. As it is stated before, both schools use two curriculum namely Cambridge curriculum and Kurikulum 2013. Therefore, there will be several different things between the curriculums. For example, the course subject. In Cambridge curriculum, there is a course subject called as Global Perspective. The novice teacher considered this course as a new thing. Therefore, it is considered as challenge for the novice teacher. To cover this challenge, the novice teacher found related information about the course as much as possible. The novice teacher tries to find the nature of the course, the example of topic in the course, and the way to teach the course. It is in line with [14], in which the teachers should pay attention and designing the teaching process that connect to the curriculum across subject areas. The novice teacher also read the guidelines in the syllabus.

The challenge above implies that the novice English teachers urgently need to learn bilingual education in their previous educational level to face this challenge. In this context, the department of English language should consider the fact that a lot of English language graduates work in bilingual environment. Therefore, it is needed to input bilingual course in the curriculum from the beginning. [16] stated that education system could be said as irrelevant if the curriculum does not enable graduates to acquire required competencies. Therefore, re-conceptualizing and repositioning curriculum need to be done to help the students to meet the expectations of the demand side of education systems [16]. Further, in the context of this research, English language learners would get benefit from re-conceptualizing and repositioning curriculum to help them face bilingual education environment. In line with that, [18] stated that curriculum development could give positive improvements in the educational system. In conclusion, curriculum planning should consider whether the products of educational system would be beneficial [20].

The second different thing that is considered as challenge for novice teacher in term of curriculum is the name and the teaching strategy of certain course from two different curriculums. For example, in Cambridge curriculum, the course is called Math and in Kurikulum 2013, the course is called Tematik. Further, the students are taught to use their mental skills to solve the questions in Cambridge curriculum. Meanwhile, the students are given formula to solve the questions in Kurikulum 2013. This thing confuse the students, especially which one is better. To solve this challenge, the novice teacher emphasize that both ways are the same and related. Besides, the novice teacher emphasize that there are various ways to solve the problem and it is the students' choice to use mental skill or formula. Therefore, the novice teachers have to adapt the teaching content and explain clearly to the students. It is in line with [6] who stated that the teachers in bilingual schools have to adapt the teaching content in certain courses. Moreover, [14] adds that the teachers need to pay attention to the details for effective learning strategies.

The other challenge in term of curriculum is the additional assignment or task in English as in Cambridge curriculum. In this case, both the curriculum used have guidelines called as "Teachers' Guide" for Cambridge curriculum and "Buku Pedoman Guru" for Kurikulum 2013. Thus, the novice teacher could look for guidance from the guidelines. Besides, discussing with other teachers also greatly help the novice teachers to cover their challenge in term of curriculum. [10] has the same opinion, in which guidance from other teacher of how to plan and use the curriculum could help novice teachers to plan and prepare the learning process. Besides, having knowledge sharing with the senior teachers could increase the value of the knowledge in natural way [4]. 
The last challenge is external challenge named students' attitudes. All of the subjects teach lower primary students. In this case, the lower primary students have different characteristics and different ways to be treated. In addition, there are also several special needs students such as talkative, hyperactive, and introvert students. In line with that, lower primary students have short focus during the learning process and they tend to playing or talking with friends during the learning process. To cover this challenge, the novice teachers approach the students with different ways. It is as the same with the special needs students. Because the students are lower primary students, creating meaningful media or designing fun learning activity could attract the students in the learning process. Besides, the novice teachers always remind that both the teacher and the students need to become each other listener. The students should listen to the teacher's explanation and the teacher should become a good listener for the students. Appreciating the students' work, even the smallest thing also effective to solve the problem with the students' attitudes. [14] has the same opinion, in which the teachers need to provide individual support and guidance for the students.

The other external challenge in term of students' attitudes is how to deal with students from non-English and nonIndonesian speaking countries such as Japan, Korea, and Russia. Because they does not have any prior knowledge about Bahasa Indonesia, the novice teachers will give extra class for them to help the students. This kind of extra class or also called as pull out program provide additional instruction for minority language students in bilingual school [23]. In addition, the novice teachers will explain carefully since the students are lower primary students who need extra treatment. The same opinion comes from [29], providing preparation class at the beginning of semester for the students who struggle in using English or Bahasa Indonesia to communicate will help the students a lot.

\section{2.. Novice English Teachers' Problems in Bilingual School and the Solutions}

Based on the result of questionnaire and interview, it shows that the novice teachers' problems in bilingual schools are classified into internal and external problems. The internal problem is teaching preparation. Meanwhile, the external problem is relationship with other parties.

The first internal problem is teaching preparation. In line with the use of two curriculum, it also affect the novice teachers' teaching preparation. To deal with this problem, the novice teachers read related books, looking for related information, follow the guidelines from school, and asking for solution to the senior teachers. In line with that, [26] supported that support from experienced teachers could help novice teachers feel confident and competent. The other solution is by maximizing the use of technology such as YouTube, Pinterest, and other search engine to look for inspiration when designing and preparing the teaching. In other words, novice teachers should create innovation or develop their creativity during the learning process [3]. Further, have a good preparation before the teaching and learning process could help maximixing the learning outcomes. It is supported by [16], in which teachers' preparation and development is considered as the steps to achieve the desired outcomes for the students.

The other problem in teaching preparation as internal problem is the activities and assessment preparation. Sometimes, it is quite difficult for the novice teacher to prepare the teaching. Therefore, the novice teachers will follow the guidance given from the school. For example, in the minor subjects (Health Education, Computer/ICT, and $\mathrm{PE})$ the learning process will be designed to suit formative learning process and use formative assessment. Meanwhile, in the major subject (Tematik, Science, and Math) the learning process will be designed to suit summative learning process and formative assessment. In addition, the novice teachers will look for suggestion from the senior teachers and follow training or workshop from expert. In line with that, [6] and [23] stated that appropriate and extensive training for teachers is needed in bilingual school. [26] added that mentoring novice teachers is important strategy for training bilingual educators. It is because mentoring could help decreasing the number of teachers who leave because the lack of knowledge and experience in bilingual environment.

The last problem is external problem named relationship with other parties. One of the subject struggle in maintaining relationship with foreign teachers. To solve this problem, the novice teacher tries to become as patient as possible. It is because the novice teacher wants to keep a good relationship with other colleagues. [3] supported that novice teachers should build a good relationship and network with other teachers.

The other subject also face problem with the parents. To solve this problem, the subject tries her best to explain the problems as polite as possible. The novice teacher believe that it could help in dealing with the parents. Besides, the subject emphasize that communication is the most important thing. Therefore, it is important to keep a continuous communication with the parents because parents highly contributed to their children development. [21] has the same opinion, in which parents participation is critical for the success of their children education. Appreciating and reminding the parents about their children progress are also important to maintain the relationship with the parents. It is supported by [14], in which by involving the learners' parents, the teachers could understand the social, linguistic, and cultural contexts of the students.

\section{CONCLUSION}

From the study, it could be concluded that the novice English teachers challenges and problems in bilingual schools context in Bali were assessment, curriculum, students' attitudes, teaching preparation, and relationship with other parties. Those challenges and problems reflected that the 
teaching and learning process in bilingual schools context is quite different with regular school as could be seen from the use of two different curriculums that affecting the other aspects such as the assessment, the teaching preparation, and the students learning process. Therefore, maximizing teacher training, workshop, and seminar will help the novice teachers to maximize their professional development. Besides, it implies that the curriculum used in their previous education level need to consider the fact that a lot of novice English teachers are work in bilingual environment. Thus, adjusting the curriculum could help the novice English teachers preparing themselves in bilingual environment.

\section{AUTHORS' CONTRIBUTIONS}

Greatest appreciation and sincere gratitude are addressed to the advisor for the guidance, correction, as well as suggestion and the novice teachers mentioned in this study who are willingly become the subject of this study.

\section{ACKNOWLEDGMENT}

This study would not have been possible without the support from the advisor, Made Hery Santosa, Ph.D. The writer also grateful for the English novice teachers mentioned in this study.

\section{REFERENCES}

[1] G. Ahmed, W.U.N. Faizi, S. Akbar, Challenges of novice teachers and strategies to cope at secondary level, Global Regional Review V(1) (2020) 403-416. DOI: 10.31703/grr.2020(V-I).44

[2] S.P. Akutina, A.N. Akutina, Problems in collaboration between multilingual children with teachers in the Italian Republic, in: Proceedings IFTE, 2020, pp. 45-58

[3] F. Anggraini, Self development of novice teacher of English: Challenges and opportunities, Lingua, Jurnal Bahasa \& Sastra 20(1) (2019) 39-43

[4] S. Areekkuzhiyil, Attitude towards knowledge sharing among under graduate students in Kerala, Edutracks 18(7) (2019) 25-31

[5] J. Baret, G. Jones, E. Mooney, C. Thornton, J. Cady, P. Guinee, J. Olson, Working with novice teachers: Challenges for professional development, Mathematics Teacher Education and Development 4 (2020) 15-27

[6] R. Breeze, J.G. Laborda, Issues in teacher education for bilingual schools, Estudios Sobre Educacion 31 (2016) 912. DOI: $10.15581 / 004.31 .9-12$

[7] M. L. Pérez-Cañado, Teacher training needs for bilingual education: In-service teacher perceptions, International Journal of Bilingual Education and Bilingualism (2014) 130

[8] N. Dash, B.C. Das, Linguistically responsive teaching framework for multilingual contexts: Problems and issues with reference to multi-lingual education in inclusive classroom, JETIR 6(1) (2019) 379-384

[9] M.F. Deocampo, Issues and challenges of English language teacher-trainees' teaching practicum performance: Looking back and going forward, LEARN Journal 13(2) (2020) 486503
[10] S.L. Dias-Lacy, R.V. Guirguis, Challenges for new teachers and ways of coping with them, Journal of Education and Learning 6(3) (2017) 265-272

[11] P. Gao, On the problems of bilingual teaching - in perspective of a teacher, Asian Social Science 4(12) (2008) $50-52$

[12] E. Gultom, Assessment and evaluation in EFL teaching and learning, in: Proceedings of ISELT-4, 2016, pp. 190-198

[13] D.R. Hancock, B. A, Doing case study research, Teachers College Press (2006)

[14] S. Kaptingei, The challenges of learners with diverse linguistic needs: Experiences of teachers in Uasin Gishu County, Kenya, British Journal of Education 4(9) (2016) $70-78$

[15] J.K. Lartec, A.M. Belisario, J.P. Bendanillo, H.K. Binas-o, N.O. Bucang, J.L.W. Cammagay, Strategies and problems encountered by teachers in implementing mother tongue based instruction in a multilingual classroom, The IAFOR Journal of Language Learning 1(1) (2014) 1-16

[16] B. N. Lawyer, Curriculum implementation in the $21^{\text {st }}$ century classroom: Dynamics and challenges for Cameroon education sector, International Journal of Humanities Social Sciences and Education 6(8) (2019) 142-152

[17] M.B. Miles, A.M. Huberman, Qualitative data analysis, SAGE Publications (1994)

[18] K. Mohanasundaram, Curriculum design and development, Journal of Applied and Advanced Research (2018) 54-56

[19] Nurdiana, Language teacher assessment literacy: A current review, Journal of English Language and Culture 11(1) (2020) 66-74

[20] G. C. Offorma, Integrating components of culture in curriculum planning, International Journal of Curriculum and Instruction 8(1) (2016) 1-8

[21] P.S. Oktarina, The teachers' perspectives towards the literacy program developed at a bilingual school, Yavana Bhasha: Journal of English Language Education 2(1) (2019) 103-120

[22] M. Öztürk. A. Yildirim, Adaption challenges of novice teachers', H. U. Journal of Education 28(1) (2013) 294-307

[23] D. Rusmawaty, Cultural diversity in bilingual education, BASTRA 1(1) (2014) 47-60

[24] C. Sclafani, Strategies for educators of bilingual students: A critical review of literature, International Journal of Education \& Literacy Studies 5(2) (2017) 1-8

[25] P. Sibanda, L.D.N. Tlale, Challenges experienced in the practice of sign bilingual education as a strategy for inclusion of dead children in mainstream schools in Zimbabwe, Journal of Social Sciences and Humanities 16(1) (2019) 1-12

[26] M. E. Torres-Guzman, A. L. Goodwin, Mentoring bilingual teachers, NCBE FOCUS: Occasional Papers in Bilingual Education 12 (1995) 1-12

[27] S. Veenman, Perceived problems of beginning teachers, Review of Educational Research 54(2) (1984) 143-178

[28] H. Wati, The effectiveness of Indonesian English teachers training programs in improving confidence and motivation, International Journal of Instruction 4(1) (2011) 79-104

[29] A. Widodo, S.R. Dewi, Revealing problems on teaching English for young learners at Al - Azhar 55 Islamic Primary School Yogyakarta and how to solve them, Varia Pendidikan 30(2) (2018) 21-29 